\title{
Fish distribution in watersheds of the eastern part of the Serra da Mantiqueira (state of São Paulo)
}

\author{
Braga, FMS. ${ }^{a *}$, Carmassi, AL. ${ }^{b}$, Rondineli, G. $^{b}$ and Lourenço, JMRMF. ${ }^{c}$ \\ ${ }^{a}$ Departamento de Zoologia, Instituto de Biociências, Universidade Estadual Paulista Júlio de Mesquita Filho - UNESP, \\ Av. 24A, 1515, Bela Vista, CEP 13506-900, Rio Claro, SP, Brazil \\ ${ }^{b}$ Centro de Ciências da Natureza, Universidade Federal de São Carlos - UFSCar, Campus Lagoa do Sino, Rodovia Lauri \\ Simões de Barros, Km 12 - SP 189, Bairro Aracaçu, CEP 18290-000, Buri, São Paulo, Brazil \\ 'Instituto de Geociências, Universidade Estadual Paulista Júlio de Mesquita Filho - UNESP, \\ Av. 24A, 1515, Bela Vista, CEP 13506-900, Rio Claro, SP, Brazil \\ *e-mail: fmsbraga@rc.unesp.br
}

Received July 31, 2012 - Accepted March 22, 2013 - Distributed May 31, 2014

(With 1 figure)

\begin{abstract}
The present work aims to analyse jointly four contiguous watersheds in the eastern part of the Serra da Mantiqueira with respect to the distribution of fish fauna and physical structure. The watersheds of Piracuama river, Ribeirão Grande, Buenos and Guaratinguetá are located in Pindamonhangaba, Campos do Jordão and Guaratinguetá municipalities, in the state of São Paulo. Data were collected between the years 2001 and 2010, with collections distributed throughout the seasons, including sites located on the slope and piedmont. The limnological parameters analysed were different between watersheds and habitat structure was different only for the slope segments between Ribeirão Grande and Buenos watersheds, and between Ribeirão Grande and Piracuama watersheds. Thirty-five species of fish were caught, with the highest species richness found in the Ribeirão Grande watershed (30 species), followed by the Piracuama (23 species) and Buenos and Guaratinguetá (21 species each). The most abundant species in both the segments (slope and piedmont) was Trichomycterus itatiayae. The highest degree of species dominance occurred in the Guaratinguetá watershed and in the segment slope, being T. itatiayae the dominant species. Species diversity was lower at the slope than the piedmont, indicating variability in species abundance. Again T. itatiayae was the most abundant species in both segments, showing to be a well adapted species to these streams systems by presenting, as well as other species, morphological adaptations to the stream environment.
\end{abstract}

Keywords: icthyofauna, species diversity, altitudinal gradient.

\section{Distribuição de peixes em microbacias da serra da Mantiqueira oriental (Estado de São Paulo)}

\section{Resumo}

O presente trabalho tem por objetivo analisar conjuntamente quatro microbacias contíguas na serra da Mantiqueira oriental com respeito à distribuição da ictiofauna e estrutura física. As microbacias do rio Piracuama, do Ribeirão Grande, do ribeirão dos Buenos e do rio Guaratinguetá situam-se nos municípios de Pindamonhangaba, Campos do Jordão e Guaratinguetá, no estado de São Paulo. Os dados foram coletados entre os anos de 2001 e 2010, sendo as coletas distribuídas ao longo das estações e contemplando pontos localizados na encosta e no pediplano. Os parâmetros limnológicos analisados foram diferentes entre as microbacias e a estrutura de habitat foi diferente apenas para os segmentos de encosta entre as microbacias do Ribeirão Grande e Buenos, e entre Ribeirão Grande e Piracuama. Trinta e cinco espécies de peixes foram capturadas, sendo a maior riqueza de espécies encontrada na microbacia do Ribeirão Grande (30 espécies), seguida pela do rio Piracuama (23 espécies) e dos Buenos e Guaratinguetá (21 espécies cada). A espécie mais abundante tanto na encosta como pediplano foi Trichomycterus itatiayae. O maior grau de dominância de espécies ocorreu na microbacia do Guaratinguetá e no segmento de encosta, sendo T. itatiayae a espécie dominante. A diversidade de espécies para encosta foi inferior à do pediplano, indicando variabilidade na abundância das espécies. Novamente T. itatiayae foi a espécie mais abundante nos dois segmentos, espécie bem adaptada a esses sistemas de riachos por apresentar, assim como outras espécies, adaptações morfológicas ao ambiente de riachos torrentosos.

Palavras-chave: ictiofauna, diversidade de espécies, gradiente altitudinal. 


\section{Introduction}

The Serra do Mar and Serra da Mantiqueira complex was formed from the reactivation of ancient faults in the early Tertiary (Petri and Fúlfaro, 1983). These faults formed the graben of the Paraíba Valley in the OligoceneMiocene, an extensive sedimentation plain that gave rise to a large lake, that drained, formed the Paraiba do Sul river (Moraes, 1945).

The Serra da Mantiqueira is located between the states of São Paulo, Minas Gerais and Rio de Janeiro, being a watershed for the basins of the Paraiba do Sul river and Grande river. According to Ponçano et al. (1981), the Serra da Mantiqueira is comprised of two sections: mountains in the east and west, which have distinct geological features. The mountains of the eastern Mantiqueira comprise the Itatiaia massif (RJ) and plateau of Campos do Jordão (SP), extending to the locality of Monteiro Lobato (SP). This part of the mountains is characterised by elevations above 1,900 $\mathrm{m}$ in Campos do Jordão and 2,400 $\mathrm{m}$ in the highlands of Itatiaia. The face for the state of Minas Gerais constitutes the mar de morros (Ab'Sáber, 1966) while the side facing the Paraíba Valley is formed by steep cliffs and rugged formations (Ponçano et al., 1981). The Serra da Mantiqueira continues northeast towards Poços de Caldas presenting less steep topography and lower altitudes.

In the plateau region of Campos do Jordão, from the slopes to the Paraíba Valley, Hueck (1972) identified several forest formations associated with altitude and rainfall. However, such vegetation is now restricted to only some areas as a result of deforestation that started in the nineteenth century as a result of coffee planting (Dean, 1996), and today from the expansion of grazing and urbanisation.
From the eastern slopes of the mountains of the Serra da Mantiqueira that face the Paraíba Valley, numerous streams will empty into the left bank of the Paraíba do Sul river. These streams form systems that are separated by ridges of hills. This relief is of recent configuration, resulting from seismic tremors that occurred between 10 thousand and three thousand years ago (Clapperton, 1993; Modenesi-Gauttieri et al., 2002). Braga (2004) defined these different river systems, separated by ridges of the hill, as watersheds. Over the past few years, several watersheds have been studied with a focus on fish fauna, resulting in works on distribution (Braga, 2004; Braga, 2005a; Braga and Andrade, 2005; Ingenito and Buckup, 2007; Rondineli et al., 2011), feeding (Braga, 2005b; Braga and Gomiero, 2009), and population biology (Braga et al., 2007; Braga et al., 2009).

The present work aims to analyse jointly four contiguous watersheds in the eastern part of the Serra da Mantiqueira in relation to the distribution of fish fauna and their physical structure.

\section{Material and Methods}

\subsection{Study area}

The watersheds studied are situated on the slopes of the eastern part of the Serra da Mantiqueira in the municipalities of Pindamonhangaba, Campos do Jordão and Guaratinguetá, in the state of São Paulo. The watersheds of Piracuama (164.43 km²), Ribeirão Grande $\left(133.76 \mathrm{~km}^{2}\right)$, Buenos $\left(84.31 \mathrm{~km}^{2}\right)$ and Guaratinguetá $\left(162.31 \mathrm{~km}^{2}\right)$ are distributed from west to east (Figure 1).

The local relief can be summarised in four configurations: plateau, hillslope, piedmont and valley. The plateau is

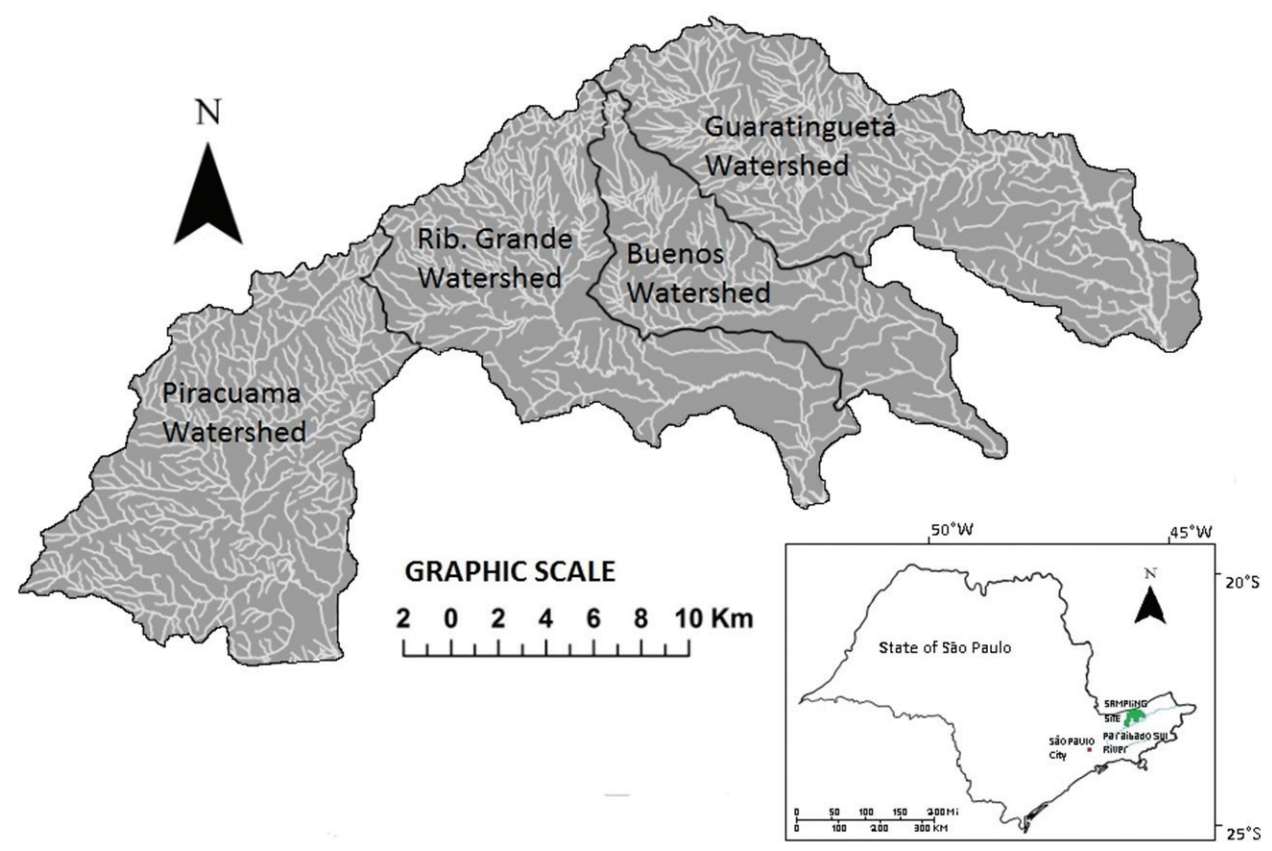

Figure 1. Watershed sites in the eastern parts of the Serra da Mantiqueira, state of São Paulo. 
located at the top of the slopes, at altitudes between 1,900 and $1,700 \mathrm{~m}$, with the characteristic landscape of high mountain grasslands, wetlands and floodplains (ModenesiGauttieri et al., 2002). The streams that form the watersheds have their sources in these areas of wetlands. The hillslope is located between 1,700 and $800 \mathrm{~m}$, being generally steep and rugged. In the higher parts, where the humidity is higher, mata de neblina occurs, which is replaced in the lower parts by mata pluvial (Hueck, 1972). At the base of the hilllslope in the transition area to the plain of the valley, at an altitude of 800-600 m, piedmont occurs, an ecotone area characterised by flat hills and currently being taken over by agricultural areas. The next configuration is the plain of the Paraiba Valley, situated around $500 \mathrm{~m}$ altitude. This region is densely populated, but relicts of semi-dry forests of Paraíba Valley still remain in some places.

\subsection{Data collection}

The data were collected in 2001 and 2002, in streams of the Ribeirão Grande watershed (Braga and Andrade, 2005), in the years of 2008 and 2009, in streams of the Buenos and Guaratinguetá watersheds (Rondineli, 2010), and in the years of 2009 and 2010 in streams of the Piracuama watershed (Carmassi, 2012). The samples were distributed over the years during the spring, summer, autumn and winter (Table 1).

Each sampling lasted five days. Every stream in each watershed was sampled using an electric fishing machine, which produced a direct electric current from 300 to $500 \mathrm{~V}$ and $8.7 \mathrm{~A}$. The sampling was made in a stretch of 50 metres with just one repetition. The specimens collected were placed in $10 \%$ formalin in the laboratory and transferred to $70 \%$ alcohol, identified and quantified.

At each sampling site and during each sampling period data were obtained for the physical and chemical variables of water such as conductivity, water temperature, dissolved oxygen and $\mathrm{pH}$. Dissolved oxygen was determined in the laboratory by the Winkler method (Moraes, 2001) and the other variables measured with electronic water analysers.

The variables of habitat structures such as depth, current velocity and substrate type were made using methods described in Gorman and Karr (1978). During the dry season (July) stretches of $50 \mathrm{~m}$ in an upstreamdownstream direction were sampled. At each $5 \mathrm{~m}$, on the left to right margin, on sites with an interval of $1 \mathrm{~m}$ in the width of the stream, the depth with a ruler in centimetres, current speed with a mechanical flowmeter and the type of substrate of visual form (Table 2) were measured. Landscape physiographic features were observed and recorded during all sampling periods.

\subsection{Data analysis}

The assessment of watershed areas was accomplished through the construction of the delimited polygons from the watersheds found on topographical maps of the Brazilian Institute of Geography and Statistics - IBGE (Brasil, 1971a, b, 1974a, b, 1975, 1982) that were digitally geo-referenced and processed in the Geographic Information System-GIS ArcGis 9.3 based on the procedures adopted and described by Lourenço (2009) who also used GIS tools in the study of fish ecology in the Buenos watershed. After generating a database in the GIS, the areas were obtained and it was possible to prepare and present maps (layouts).

The physical and chemical variables of water between watersheds were analysed using the non-parametric test of Kruskal-Wallis test (Siegel, 1975) followed by the "a posteriori" Dunn test (Vanzolini, 1993), when there was significance in test $(\mathrm{P}<0.05)$.

The analysis of the habitat characterisation between watersheds was performed using the Friedman non-parametric test for related samples (Siegel, 1975), comparing the numerical frequencies of each structural category between

Table 1. Sample sites in Piracuama (P). Ribeirão Grande (RG), Buenos (B) and Guaratinguetá (G) watersheds, state of São Paulo; monitored stream, geographic coordinates and segment of the collection site.

\begin{tabular}{|c|c|c|c|}
\hline Site & Stream & Coordinate & Segment \\
\hline $\mathrm{P} 1$ & Piracuama & $22^{\circ} 49^{\prime} 43^{\prime \prime} \mathrm{S} 45^{\circ} 35^{\prime} 31^{\prime \prime W}$ & Hillslope \\
\hline $\mathrm{P} 2$ & Piracuama & $22^{\circ} 50^{\prime} 57^{\prime \prime} \mathrm{S} 45^{\circ} 36^{\prime} 04^{\prime \prime} \mathrm{W}$ & Piedmont \\
\hline P3 & Piracuama & $22^{\circ} 52^{\prime} 04^{\prime \prime} \mathrm{S} 45^{\circ} 35^{\prime} 07^{\prime \prime} \mathrm{W}$ & Piedmont \\
\hline P4 & Oliveiras & $22^{\circ} 48^{\prime} 36^{\prime \prime} \mathrm{S} 45^{\circ} 31^{\prime} 33^{\prime \prime} \mathrm{W}$ & Hillslope \\
\hline P5 & Oliveiras & $22^{\circ} 48^{\prime} 51^{\prime \prime S} 45^{\circ} 32^{\prime} 28^{\prime \prime} \mathrm{W}$ & Hillslope \\
\hline P6 & Oliveiras & $22^{\circ} 50^{\prime} 42^{\prime \prime} \mathrm{S} 45^{\circ} 34^{\prime} 55^{\prime \prime} \mathrm{W}$ & Piedmont \\
\hline RG1 & Cedro & $22^{\circ} 45^{\prime} 02^{\prime \prime S} 45^{\circ} 27^{\prime} 58^{\prime \prime} \mathrm{W}$ & Hillslope \\
\hline RG2 & Cedro & $22^{\circ} 46^{\prime} 24^{\prime \prime} \mathrm{S} 45^{\circ} 27^{\prime} 50^{\prime \prime} \mathrm{W}$ & Hillslope \\
\hline RG3 & Canjarana & $22^{\circ} 46^{\prime} 07^{\prime \prime} \mathrm{S} 45^{\circ} 27^{\prime} 52^{\prime \prime} \mathrm{W}$ & Piedmont \\
\hline RG4 & Ferraz & $22^{\circ} 47^{\prime} 48^{\prime \prime} \mathrm{S} 45^{\circ} 28^{\prime} 59^{\prime \prime} \mathrm{W}$ & Piedmont \\
\hline RG5 & Ribeirão Grande & $22^{\circ} 48^{\prime} 25^{\prime \prime} \mathrm{S} 45^{\circ} 26^{\prime} 56^{\prime \prime} \mathrm{W}$ & Piedmont \\
\hline RG6 & Ribeirão Grande & $22^{\circ} 48^{\prime} 59^{\prime \prime} \mathrm{S} 45^{\circ} 25^{\prime} 22^{\prime \prime}$ & Piedmont \\
\hline B1 & Buenos & $22^{\circ} 46^{\prime} 31^{\prime \prime} \mathrm{S} 45^{\circ} 24^{\prime} 44^{\prime \prime}$ & Hillslope \\
\hline B2 & Buenos & $22^{\circ} 47^{\prime} 43^{\prime \prime} \mathrm{S} 45^{\circ} 17^{\prime} 53^{\prime \prime}$ & Piedmont \\
\hline G1 & Taquaral & $22^{\circ} 43^{\prime} 29^{\prime \prime} \mathrm{S} 45^{\circ} 20^{\prime} 37^{\prime \prime}$ & Hillslope \\
\hline $\mathrm{G} 2$ & Pirutinga & $22^{\circ} 44^{\prime} 25^{\prime \prime} \mathrm{S} 45^{\circ} 22^{\prime} 24^{\prime \prime}$ & Piedmont \\
\hline
\end{tabular}


the watersheds. For significant difference $(\mathrm{P}<0.05)$ a "a posteriori” test was used (Campos, 1983). In this analysis the sites situated on the slope and piedmont were considered separately.

The species diversity for the watersheds was analysed using the species dominance index of Berger-Parker (d) that also estimates the evenness (Magurran, 1991). Species diversity between the slope and piedmont was analysed using the Shannon index, which allows the use of t-test after the variance estimate (Magurran, 1991).

\section{Results}

Table 3 summarises the results found in the KruskalWallis test for data of the physical and chemical variables of water in the watersheds analysed. The results showed significant differences $(\mathrm{P}<0.05)$ in limnological parameters measured in the streams. The "a posteriori" Dunn test showed that in some cases the parameters were similar between watersheds while in others there was a significant difference, demonstrating a degree of heterogeneity among watersheds in relation to these limnological parameters.

Table 2. Description of categories (depth, current velocity and substrate) and the type and size used to describe the different habitats where fish were sampled in different streams.

\begin{tabular}{|c|c|c|}
\hline Category & Type & Size \\
\hline \multirow[t]{2}{*}{ depth $(\mathrm{cm})$} & shallow & between 0 and 30 \\
\hline & moderate & between 30 and 100 \\
\hline \multirow{5}{*}{$\begin{array}{c}\text { Current } \\
\text { velocity }(\mathrm{m} / \mathrm{s})\end{array}$} & very slow & $<0.05$ \\
\hline & slow & between 0.05 and 0.2 \\
\hline & moderate & between 0.2 and 0.4 \\
\hline & fast & between 0.4 and 1.0 \\
\hline & torrent & $>1,0$ \\
\hline \multirow{5}{*}{$\begin{array}{l}\text { substrate } \\
(\mathrm{mm})\end{array}$} & sand & between 0.05 and 2.0 \\
\hline & gravel & between 2.0 and 10.0 \\
\hline & pebble & between 10.0 and 100.0 \\
\hline & stone & between 100.0 and 300.0 \\
\hline & boulder & $>300.0$ \\
\hline
\end{tabular}

The Friedman test applied to the structural characteristics of the streams located on the slope of the watersheds showed a significant result $\left(\mathrm{c}^{2}=30.9, \mathrm{P}<0.001\right)$. The "a posteriori" test showed no difference $(\mathrm{P}<0.05)$ between structures of habitats in the segments of the slope for Ribeirão Grande and Buenos watersheds, and for Ribeirão Grande and Piracuama. The Friedman test applied to streams of watersheds located in piedmont was not significant $\left(c^{2}=4.48, P>0.05\right)$, indicating that there is no distinction of habitats in that segment.

Table 4 lists the 35 species of fish taken in the four watersheds. The highest species richness was found in the Ribeirão Grande watershed, with 30 species, followed by the Piracuama with 23 species and the Buenos and Guaratinguetá watersheds, with 21 species each. As for the abundance of individuals, the Ribeirão Grande watershed was the one with the largest number of individuals captured (2,792 individuals), followed by the Piracuama (1,641 individuals), Guaratinguetá (1,470 individuals) and Buenos ( 1,057 individuals).

Table 5 shows the occurrences of the 35 species collected at four watersheds studied in the segments of slope and piedmont. The most abundant species in both the segments was Trichomycterus itatiayae Miranda-Ribeiro, 1939. On the hillslope occurs 17 species and on the piedmont 33 species. Of these, 15 species were common to the slope and piedmont, while two species were unique to the slope and 18 for piedmont.

The results from the dominance index of Berger-Parker applied to the distribution of species in the four watersheds (Table 4) show that the highest degree of species dominance occurred in the Guaratinguetá watershed $(\mathrm{d}=0.692)$ with the lowest equitability $(1 / \mathrm{d}=1.445)$ where the dominant species was Trichomycterus itatiayae. The Ribeirão Grande watershed showed the lowest value of dominance $(\mathrm{d}=0.191)$ and the highest value of evenness $(1 / \mathrm{d}=5.236)$. When hillslope and piedmont were analysed, it was found that the Berger-Parker index value was greater on the slope $(\mathrm{d}=0.448)$ showing lower values of evenness $(1 / \mathrm{d}=2.232)$. Also in this case there was a preponderance of $T$. itatiayae in relation to other species (Table 5).

Table 6 presents the results of the Shannon index applied to the fish distribution into the watersheds considering the slope and piedmont segments. The index value estimated

Table 3. Results of Kruskal-Wallis test $(\mathrm{H})$ for the physicochemical characteristics of the Piracuama (P), Ribeirão Grande $(R G)$, Buenos (B) and Guaratinguetá $(G)$ watersheds and the "a posteriori" Dunn test. $* P<0.05$. Values outside parentheses represent median values, inside parentheses represent the mean values of ordinations allocated and used in the test.

\begin{tabular}{|c|c|c|c|c|c|}
\hline Characteristics & $\mathbf{P}$ & RG & B & $\mathbf{G}$ & $\mathbf{H}$ \\
\hline \multirow[t]{2}{*}{ Conductivity ( $\mu \mathrm{s} / \mathrm{cm})$} & $33.1(50.2)$ & $15.0(17.8)$ & $20.0(35)$ & $25.9(42.7)$ & $28.4^{*}$ \\
\hline & RG-G*, RG-P* & & & & \\
\hline \multirow[t]{2}{*}{ Temperature $\left({ }^{\circ} \mathrm{C}\right)$} & $21.0(30.6)$ & $18.6(22.4)$ & $25.4(3.2)$ & $22.0(2.8)$ & $25.4 *$ \\
\hline & P-G*, P-B* & & & & \\
\hline \multirow[t]{2}{*}{ Oxygen (mg/L) } & $9.7(33.9)$ & $9.4(29.3)$ & $9.1(19.40)$ & $8.8(11.4)$ & $16.8 *$ \\
\hline & RG-G*, P-G* & & & & \\
\hline \multirow[t]{2}{*}{$\mathrm{pH}$} & $7.0(26.5)$ & $7.7(51.6)$ & $6.1(7.8)$ & $6.9(17.8)$ & $48.3 *$ \\
\hline & \multicolumn{5}{|c|}{ RG-G*, RG-G* ${ }^{*}, \mathrm{RG}-\mathrm{P}^{*}$} \\
\hline
\end{tabular}


Table 4. List of species caught in the four watersheds and their respective abundances and values of the Berger-Parker index (d) and evenness $(1 / \mathrm{d})$.

\begin{tabular}{|c|c|c|c|c|c|}
\hline Species & Piracuama & R.Grande & Buenos & Guaratinguetá & Total \\
\hline Trichomycterus itatiayae Miranda-Ribeiro, 1939 & 636 & 500 & 311 & 1017 & 2464 \\
\hline Characidium lauroi Travassos, 1949 & 191 & 532 & 157 & 60 & 940 \\
\hline Neoplecostomus microps (Steindachner, 1877) & 316 & 249 & 106 & 65 & 736 \\
\hline Characidium alipioi Travassos, 1955 & 26 & 520 & 43 & 12 & 601 \\
\hline Pareiorhina rudolphi (Miranda-Ribeiro, 1911) & 71 & 277 & 2 & 60 & 410 \\
\hline Astyanax intermedius Eigenmann, 1908 & 102 & 213 & 5 & 15 & 335 \\
\hline Phalloceros caudimaculatus (Hensel, 1868) & 10 & 17 & 280 & 3 & 310 \\
\hline Harttia carvalhoi Miranda-Ribeiro, 1939 & 118 & 46 & 13 & 69 & 246 \\
\hline Trichomycterus iheringi (Eigenmann, 1917) & 10 & 30 & 41 & 42 & 123 \\
\hline Rineloricaria kronei (Miranda-Ribeiro, 1911) & 0 & 85 & 15 & 17 & 117 \\
\hline Imparfinis minutus (Lütken, 1874) & 0 & 100 & 0 & 0 & 100 \\
\hline Astyanax bimaculatus (Linnaeus, 1758) & 5 & 24 & 50 & 11 & 90 \\
\hline Taunayia bifasciata (Eigenmann \& Norris, 1900) & 34 & 43 & 0 & 2 & 79 \\
\hline $\begin{array}{l}\text { Pareiorhina brachyrhyncha Chamon, Aranda \& } \\
\text { Buckup, } 2005\end{array}$ & 0 & 5 & 10 & 50 & 65 \\
\hline Geophagus brasiliensis (Quoy \& Gaimard, 1824) & 15 & 32 & 0 & 2 & 49 \\
\hline Hypostomus spp. & 20 & 21 & 0 & 6 & 47 \\
\hline $\begin{array}{l}\text { Trichomycterus immaculatus (Eigenmann \& } \\
\text { Eigenmann, 1889) }\end{array}$ & 21 & 23 & 0 & 0 & 44 \\
\hline $\begin{array}{l}\text { Ancistrus stigmaticus Eigenmann \& Eigenmann, } \\
1889\end{array}$ & 1 & 0 & 2 & 31 & 34 \\
\hline Astyanax fasciatus (Cuvier, 1829) & 21 & 5 & 2 & 1 & 29 \\
\hline Oligosarcus hepsetus (Cuvier, 1929) & 20 & 2 & 2 & 0 & 24 \\
\hline Gymnotus pantherinus (Steindachner, 1908) & 0 & 12 & 10 & 0 & 22 \\
\hline Rhamdia quelen (Quoy \& Gaimard, 1824) & 12 & 6 & 0 & 2 & 20 \\
\hline Trichomycterus alternatus (Eigenmann, 1917) & 5 & 13 & 0 & 0 & 18 \\
\hline Gymnotus carapo Linnaeus, 1758 & 0 & 5 & 1 & 3 & 9 \\
\hline Pimelodus maculatus Lacèpede, 1803 & 0 & 7 & 0 & 0 & 7 \\
\hline Rineloricaria steindachneri (Regan, 1904) & 0 & 7 & 0 & 0 & 7 \\
\hline Synbranchus marmoratus Bloch, 1795 & 1 & 3 & 2 & 1 & 7 \\
\hline Hoplosternum littoralis (Hancock, 1828) & 2 & 3 & 0 & 1 & 6 \\
\hline Rhamdia sp. & 2 & 3 & 0 & 0 & 5 \\
\hline Hisonotus sp. & 0 & 5 & 0 & 0 & 5 \\
\hline Hoplias malabaricus (Bloch, 1794) & 0 & 4 & 0 & 0 & 4 \\
\hline Pimelodella sp. & 0 & 0 & 3 & 0 & 3 \\
\hline Characidium cf. pterostictium Gomes, 1947 & 2 & 0 & 0 & 0 & 2 \\
\hline Oncorhyncus mykiss (Walbaum, 1792) & 0 & 0 & 1 & 0 & 1 \\
\hline $\begin{array}{l}\text { Pseudotocinclus parahybae Takako, Oliveira \& } \\
\text { Oyakawa, } 2005\end{array}$ & 0 & 0 & 1 & 0 & 1 \\
\hline $\mathrm{D}$ & 0.388 & 0.191 & 0.294 & 0.692 & 1.565 \\
\hline $1 / \mathrm{d}$ & 2.577 & 5.236 & 3.401 & 1.445 & 12.659 \\
\hline Total of individuals & 1641 & 2792 & 1057 & 1470 & 6960 \\
\hline Total of species & 23 & 30 & 21 & 21 & 35 \\
\hline
\end{tabular}

for the slope was lower $\left(\mathrm{H}^{\prime}=1.645\right)$ to that estimated for the piedmont $\left(H^{\prime}=2.559\right)$. The $t$ test applied to these values showed significant difference $(\mathrm{t}=34.3, \mathrm{P}<0.001)$. The estimated values for evenness $(\mathrm{E})$ were 0.581 for the slope and 0.732 for the piedmont. These values indicate the variability in species abundance which includes the preponderance of T. itatiayae in the two segments (Table 5).

\section{Discussion}

The streams which descend to the eastern parts of the Serra da Mantiqueira have their courses driven by joints that are positioned along the slopes and once reaching the region of the valley, the route is directed by the texture of the soil sediment (Braga, 2004). Thus, 
Table 5. List of species occurring in the four watersheds considering events on the slope and piedmont. Values for the Berger-Parker (d) index and evenness $(1 / \mathrm{d})$.

\begin{tabular}{|c|c|c|c|}
\hline Species & Hillslope & Piedmont & Total \\
\hline Trichomycterus itatiayae Miranda-Ribeiro, 1939 & 1,684 & 780 & 2,464 \\
\hline Characidium lauroi Travassos, 1949 & 774 & 166 & 940 \\
\hline Neoplecostomus microps (Steindachner, 1877) & 444 & 292 & 736 \\
\hline Characidium alipioi Travassos, 1955 & 7 & 594 & 601 \\
\hline Pareiorhina rudolphi (Miranda-Ribeiro, 1911) & 332 & 78 & 410 \\
\hline Astyanax intermedius Eigenmann, 1908 & 234 & 101 & 335 \\
\hline Phalloceros caudimaculatus (Hensel, 1868) & 23 & 287 & 310 \\
\hline Harttia carvalhoi Miranda-Ribeiro, 1939 & 94 & 152 & 246 \\
\hline Trichomycterus iheringi (Eigenmann, 1917) & 4 & 119 & 123 \\
\hline Rineloricaria kronei (Miranda-Ribeiro, 1911) & - & 117 & 117 \\
\hline Imparfinis minutus (Lütken, 1874) & 8 & 92 & 100 \\
\hline Astyanax bimaculatus (Linnaeus, 1758) & 1 & 89 & 90 \\
\hline Taunayia bifasciata (Eigenmann \& Norris, 1900) & 58 & 21 & 79 \\
\hline Pareiorhina brachyrhyncha Chamon, Aranda \& Buckup, 2005 & 48 & 17 & 65 \\
\hline Geophagus brasiliensis (Quoy \& Gaimard, 1824) & - & 49 & 49 \\
\hline Hypostomus spp. & - & 47 & 47 \\
\hline Trichomycterus immaculatus. (Eigenmann \& Eigenmann, 1889) & 2 & 42 & 44 \\
\hline Ancistrus stigmaticus Eigenmann \& Eigenmann, 1889 & - & 34 & 34 \\
\hline Astyanax fasciatus (Cuvier, 1819) & - & 29 & 29 \\
\hline Oligosarcus hepsetus (Cuvier, 1829) & - & 24 & 24 \\
\hline Gymnotus pantherinus (Steindachner, 1908) & 4 & 18 & 22 \\
\hline Rhamdia quelen (Quoy \& Gaimard, 1824) & - & 20 & 20 \\
\hline Trichomycterus alternatus (Eigenmann, 1917) & 18 & - & 18 \\
\hline Gymnotus carapo Linnaeus, 1758 & - & 9 & 9 \\
\hline Pimelodus maculatus Lacèpede, 1803 & - & 7 & 7 \\
\hline Rineloricaria steindachneri (Regan, 1904) & - & 7 & 7 \\
\hline Synbranchus marmoratus Bloch, 1795 & - & 7 & 7 \\
\hline Hoplosternum littoralis (Hancock, 1828) & - & 6 & 6 \\
\hline Rhamdia sp. & 5 & - & 5 \\
\hline Hisonotus sp. & - & 5 & 5 \\
\hline Hoplias malabaricus (Bloch, 1794) & - & 4 & 4 \\
\hline Pimelodella sp. & - & 3 & 3 \\
\hline Characidium cf. pterostictium Gomes, 1947 & - & 2 & 2 \\
\hline Oncorhyncus mykiss (Walbaum, 1792) & - & 1 & 1 \\
\hline Pseudotocinclus parahybae Takako, Oliveira \& Oyakawa, 2005 & - & 1 & 1 \\
\hline Total & 3,740 & 3,220 & 6,960 \\
\hline Number of species & 17 & 33 & \\
\hline Number of common species & \multicolumn{2}{|c|}{15} & \\
\hline Number of unique species & 2 & 18 & \\
\hline d & 0.448 & 0.242 & \\
\hline $1 / \mathrm{d}$ & 2.232 & 4.132 & \\
\hline
\end{tabular}

there is a relationship between the physical aspects such as flow velocity, substrate and temperature of water, and chemical variables of water such as conductivity, $\mathrm{pH}$ and dissolved oxygen. In addition, the lithology, soil and covering vegetation area will play a fundamental role in the stream characteristics (Allan, 1995).

The recent history of paleoclimatic and geomorphological evolution of mountains of the Serra da Mantiqueira date from events that started in the Pleistocene and continued into the Holocene (Modenesi and Melhem, 1992; ModenesiGauttieri and Nunes, 1998; Modenesi-Gauttieri et al., 2002). Studies by Ebert (1960) in the highlands of Itatiaia showed evidence of altitude glaciation in the Pleistocene, but were questioned by Clapperton (1993) as having other origins (Modenesi-Gauttieri and Nunes, 1998).

In the terminal Pleistocene, 12,000 to 18,000 in recent years, southeastern Brazil was under the influence of a dry period that provoked a series of morphoclimatic mosaics 
Table 6. Results of the Shannon diversity index applied to distributions of fish in the watersheds considering hillslope and piedmont. $\mathrm{H}$ '= index value, $\mathrm{E}=$ value of evenness, Var $=$ variance of the index, $\mathrm{t}=\mathrm{t}$ value of the statistic, $\mathrm{P}=$ significance.

\begin{tabular}{cccccc}
\hline Segment & H' & E & Var & t & P \\
\hline Hillslope & 1.645 & 0.581 & 0.00031 & & \\
& & & & 34.3 & $<0.001$ \\
Piedmont & 2.559 & 0.732 & 0.00040 & & \\
\hline
\end{tabular}

and phytogeographic patterns (Ab'Sáber, 1977, 1979, 1988). The weather was predominantly dry in the lowlands and humid in the highest. In the lowlands, the vegetation was xeromorphic due to the dry climate. Paleoclimatic evidence of this climate is the presence in the landscape of stone lines.

In the study area stone lines were identified in low and middle parts of the Piracuama watershed (Carmassi, 2012), in the medial portion of the Ribeirão Grande watershed (Braga, 2005a) and in middle parts of the Buenos and Guaratinguetá watersheds (Rondineli, 2010). The locations of stone lines follow a transect at the boundary between the valley and piedmont. Therefore it appears that the piedmont, the transition zone between the hillslope and the plain, is an ecotone that in the past separated a dry zone and a wet zone. In the early Holocene, with the end of the last glacial period the climate became warmer and wetter and forests began to occupy the lower parts of slopes (Ab’Sáber, 1977).

In a zoning plan for continental-scale of rivers, many streams have its segments in the slope, piedmont and plain (Matthews, 1998). In the slope, the segment of the stream alternates riffles and pools, whereas the plain stream segment becomes more voluminous (Allan, 1995). The upper parts of a stream are called rhithron and the lower parts, potamon, and fish that inhabit these segments tend to have adaptive features for these conditions (Wootton, 1992). In rhithron these adaptations are associated with the use of habitats, such as body shape and structures developed (fins, spines) to keep the fish in the riffle environment. In potamon, the lowest current velocity, the greater width of the stream, wetland margins and proliferation of aquatic weeds, cause the fish to develop morphological adaptations for continuous swimming and physiological adaptations to meet the depletion of dissolved oxygen. Braga (2004) studied the fish fauna in streams of the Ribeirão Grande watershed and found that many species that inhabit preferentially rhithron present a reduction in gonad size and loss of bladder as adaptive features for these environments.

The species composition and diversity are common patterns to be observed along a river gradient (Horwitz, 1978; Evans and Noble, 1979; Ostrand and Wilde, 2002). These patterns are occasioned by the action of biotic and abiotic factors that act in the assemblage structure of fish in the longitudinal direction (Taylor et al., 1993). Fish species that inhabit the headwaters are more tolerant of stressful conditions, while those that inhabit the lower parts are adapted to less extreme conditions (Lohr and Fausch, 1997). Several studies associate the seasonal environmental variations to climate factors influencing community and species diversity (Matthews, 1990; Meador and Matthews, 1992; Taylor et al., 1996).

Of the 35 species recorded in the studied watersheds of the eastern Serra da Mantiqueira, 15 are common to the hillside and piedmont segments, two are exclusive to the slope and 18 are exclusive to piedmont. According to Schlosser (1982) changes in the composition of the fish fauna and an increase in species richness upstream to downstream are associated with seasonal variability, channel morphology and available resources. Braga and Gomiero (2009) found that fish from the Ribeirão Grande watershed feed mainly on insect larvae and nymphs, and this source of food is available both on slopes and piedmont. Species that occurred on the slope, such as Characidium lauroi Travassos, 1949 and C. alipioi Travassos, 1955 which prevailed in piedmont, had similar diets based mainly on insect larvae and nymphs (Braga, 2005b).

Several studies suggest that environmental variability tends to decrease moving downstream, and that this decrease is associated with an increased diversity of species (Grossman et al., 1982; Poff and Allan, 1995; Ostrand and Wilde, 2002). In the watersheds of the eastern mountains of the Serra da Mantiqueira, the environmental variability was greater among slope streams than among the piedmont streams. On the other hand, the richness and diversity of species was greater in the piedmont segment, where environmental conditions tend to be more homogeneous.

Trichomycterus itatiayae was the most abundant species among the watersheds studied. It is a species well adapted to these streams by presenting morphological adaptations to the environment of riffles, as well as Characidium spp. and catfishes (Braga, 2004). In the lower parts, in the transition from the rhithron to potamon, there were species with morphological adaptations to this environment (Wootton, 1992), such as more active swimming in the water column (Astyanax spp.), respiratory adaptations to the fall in the level oxygen (Synbranchus marmoratus Bloch, 1795), associations with macrophytes (guppies, Gymnotus spp.), sucking habits (catfish) and carnivores (Hoplias malabaricus (Bloch, 1794), Oligosarcus hepsetus (Cuvier, 1929)).

Acknowledgements - We are grateful to FAPESP and CNPq for financial support; to Prof. Dr. Francisco Langeani Neto and Prof. Dr. Heraldo Britski for fish identification; and to the "Núcleo de Educação Ambiental do Ribeirão Grande" for the logistic support.

\section{References}

Ab'SÁBER, AN., 1966. O domínio dos mares de morros no Brasil. Geomorfologia, no. 2, p. 1-19.

Ab'SÁBER, AN., 1977. Espaços ocupados pela expansão dos climas secos na América do Sul, por ocasião dos períodos glaciais quaternários. Paleoclimas, no. 3, p. 1-19. 
Ab'SÁBER, AN., 1979. Os mecanismos da desintegração das paisagens tropicais no Pleistoceno: efeitos paleoclimáticos do período Wurn-Wisconsin no Brasil. Inter-Facies, no. 4, p. 1-19.

AB'SÁBER, AN., 1988. O pantanal matogrossense e a teoria dos refúgios. Revista Brasileira de Geografia, vol. 50, p. 9-57.

ALLAN, JD., 1995. Stream ecology: structure and function of running waters. London: Chapman \& Hall. 388 p.

BRAGA, FMS. and ANDRADE, PM., 2005. Distribuição de peixes na microbacia do Ribeirão Grande, serra da Mantiqueira oriental, São Paulo, Brasil. Iheringia. Série Zoologia, vol. 95, no. 2, p. 121-126. http://dx.doi.org/10.1590/S0073-47212005000200002.

BRAGA, FMS. and GOMIERO, LM., 2009. Alimentação de peixes na microbacia do Ribeirão Grande, serra da Mantiqueira oriental, SP. Biota Neotropica, vol. 9, no. 3, p. 207-212. http:// dx.doi.org/10.1590/S1676-06032009000300021.

BRAGA, FMS., 2004. Hábitat, distribuição e aspectos adaptativos de peixes da microbacia do Ribeirão Grande, Estado de São Paulo, Brasil. Acta Scientarium, vol. 26, no. 1, p. 31-36.

BRAGA, FMS., 2005a. Spatial distribution of characidiin fishes (Teleostei, Crenuchidae) in the Ribeirão Grande system, a tributary of Paraíba do Sul river basin, Brazil. Acta Scientiarum. Biological Sciences, vol. 27, no. 3, p. 259-263.

BRAGA, FMS., 2005b. Feeding and condition factor of characidiin fish in Ribeirão Grande system, southeastern Brazil. Acta Scientarium, vol. 27, no. 3, p. 271-276.

BRAGA, FMS., GOMIERO, LM. and SOUZA, UP., 2009. Biologia populacional de Pareiorhina rudolphi (Loricariidae, Hypostominae) na microbacia do Ribeirão Grande, serra da Mantiqueira oriental, Estado de São Paulo. Acta Scientarium, vol. 31 , no. 1 , p. $79-88$.

BRAGA, FMS., SOUZA, UP. and CARMASSI, AL., 2007. Dinâmica populacional de Characidium lauroi e C. alipioi (Teleostei, Crenuchidae) na microbacia do Ribeirão Grande, serra da Mantiqueira oriental, Estado de São Paulo. Acta Scientarium, vol. 29 , no. 3, p. 281-287.

Brasil. Instituto Brasileiro de Geografia e Estatística - IBGE, 1971a. Região Sudeste do Brasil: Delfim Moreira. Folha SF23-Y-B-VI-1: carta topográfica. Rio de Janeiro: IBGE. 1 mapa, color. Escala 1:50.000.

Brasil. Instituto Brasileiro de Geografia e Estatística - IBGE, 1971b. Região Sudeste do Brasil: Campos do Jordão. Folha SF23-Y-B-V-2: carta topográfica. Rio de Janeiro: IBGE. 1 mapa, color. Escala 1:50.000.

Brasil. Instituto Brasileiro de Geografia e Estatística - IBGE, 1974a. Região Sudeste do Brasil: Pindamonhangaba. Folha SF23-Y-B-VI-3: carta topográfica. Rio de Janeiro: IBGE. 1 mapa, color. Escala 1:50.000.

Brasil. Instituto Brasileiro de Geografia e Estatística - IBGE, 1974b. Região Sudeste do Brasil: Tremembé. Folha SF-23-YB-V-4: carta topográfica. Rio de Janeiro: IBGE. 1 mapa, color. Escala 1:50.000

Brasil. Instituto Brasileiro de Geografia e Estatística - IBGE, 1975. Região Sudeste do Brasil: Lorena. Folha SF-23-Y-B-VI-2: carta topográfica. Rio de Janeiro: IBGE. 1 mapa, color. Escala 1:50.000.

Brasil. Instituto Brasileiro de Geografia e Estatística - IBGE, 1982. Região Sudeste do Brasil: Guaratinguetá. Folha SF-23-YB-VI-4-MI-2741-4: carta topográfica. Rio de Janeiro: IBGE. 1 mapa, color. Escala 1:50.000.
CAMPOS, H., 1983. Estatística experimental não-paramétrica. São Paulo: ESALQ-USP.

CARMASSI, AL., 2012. Estrutura das comunidades e biologia populacional da ictiofauna de riachos da microbacia do rio Piracuama na serra da Mantiqueira oriental. Rio Claro: Universidade Estadual Paulista. 85 p. Tese de Doutorado em Ciências Biológicas (Zoologia)

CLAPPERTON, C., 1993. Quaternary of the South America highlands. Part II: Case studies in southeast Brazil: Campos do Jordão and Serra da Itatiaia. In CLAPPERTON, CM. Quaternary geology and geomorphology of South America. Amsterdan: Elsevier. p. 243-258

DEAN, W., 1996. A ferro e fogo: a história da devastação da Mata Atlântica brasileira. São Paulo: Companhia das Letras.

EBERT, H., 1960. Novas observações sobre a Glaciação Pleistocênica na Serra do Itatiaia (Nota Preliminar). Anais da Academia Brasileira de Ciências, vol. 32, no. 1, p. 51-73.

EVANS, JW. and NOBLE, RL., 1979. The longitudinal distribution of fishes in an east Texas stream. The American Midland Naturalist Journal, vol. 101, no. 2, p. 333-334. http://dx.doi. org/10.2307/2424599.

GORMAN, OT. and KARR, JR., 1978. Habitat structure and streamfish communities. Ecology, vol. 59, no. 3, p. 507-515. http://dx.doi.org/10.2307/1936581

GROSSMAN, GD., MOYLE, PB. and WHITAKER JUNIOR, JO., 1982. Stochasticity in structural and characteristics of an Indiana stream assemblage: a test of community theory. The American Midland Naturalist Journal, vol. 120, no. 4, p. 423-454. http:// dx.doi.org/10.1086/284004.

HORWITZ, RJ., 1978. Temporal variability patterns and the distributional patterns of stream fishes. Ecological Monographs, vol. 48, no. 3, p. 307-321. http://dx.doi.org/10.2307/2937233.

HUECK, K., 1972. As florestas da América do Sul: ecologia, composição e importância econômica. São Paulo: Polígono Brasília/Universidade de Brasília.

INGENITO, LFS. and BUCKUP, PA., 2007. The serra da Mantiqueira, South-Eastern Brazil, as a biogeographical barrier for fishes. Journal of Biogeography, vol. 34, no. 7, p. 1173-1182. http://dx.doi.org/10.1111/j.1365-2699.2007.01686.x.

LOHR, SC. and FAUSCH, KD., 1997. Multiscale analysis of natural variability in stream fish assemblages of a western great plains watershed. Copeia, vol. 1997, no. 4, p. 706-724. http:// dx.doi.org/10.2307/1447289.

LOURENÇO, JMRMF.,2009. Caracterização geográfica e análise da distribuição horizontal da ictiofauna da microbacia do ribeirão dos Buenos ou Moreiras (Serra da Mantiqueira Oriental). Rio Claro: Universidade Estadual Paulista. 191 p. Dissertação de Mestrado em Geografia.

MAGURRAN, AE., 1991. Ecological diversity and its measurement. London: Chapman and Hall.

MATTHEWS, WJ., 1990. Spatial and temporal variation in fishes of riffle habitats: a comparison of analytical approaches for the Roanoke River. The American Midland Naturalist, vol. 124, no. 1, p. 31-45. http://dx.doi.org/10.2307/2426077.

MATTHEWS, WJ., 1998. Patterns in freswater fish ecology. New York: Chapman and Hall. 
MEADOR, MR. and MATTHEWS, WJ., 1992. Spatial and temporal patterns in fish assemblage structure of an intermittent Texas stream. The American Midland Naturalist, vol. 127, no. 1, p. 106-114. http://dx.doi.org/10.2307/2426326.

MODENESI, MC. and MELHEM, TS., 1992. Palynological data on a Holocene peat deposit in tropical Brazil: preliminary paleoclimatic and paleoecological interpretations. Revista do Instituto Geológico, vol. 13, no. 2, p. 7-15. http://dx.doi. org/10.5935/0100-929X.19920006.

MODENESI-GAUTTIERI, MC. and NUNES, LH., 1998. Processos geocriogênicos quaternários nas cimeiras da Mantiqueira, com considerações climáticas. Revista do Instituto Geológico, vol. 19, no. 1-2, p. 19-30.

MODENESI-GAUTTIERI, MC., TAKASHI HIRUMA, S. and RICCOMINI, C., 2002. Morphotectonics of a high plateau on the northweastern flanks of the continental rift of southeastern Brazil. Geomorphology, vol. 43, no. 3-4, p. 257-271. http://dx.doi. org/10.1016/S0169-555X(01)00137-4.

MORAES, LJ., 1945. Bacia Terciária do Vale do Paraíba, estado de São Paulo. Boletim da Faculdade de Filosofia Ciências e Letras USP-Geologia, vol. 50, no. 2, p. 3-25.

MORAES, AJ., 2001. Manual para avaliação da qualidade da água. São Carlos: RIMA.

OSTRAND, KG. and WILDE, GR., 2002. Seasonal and spatial variation in a prairie stream-fish assemblage. Ecology Freshwater Fish, vol. 11, no. 3, p. 137-149. http://dx.doi.org/10.1034/j.16000633.2002.00005.x.

PETRI, S. and FÚlFARO, VJ., 1983. Geologia do Brasil: Fanerozóico. São Paulo: T. A. Queiroz/EDUSP.

PONÇANO, WL., CARNEIRO, CDR., BISTRICHI, CA., ALMEIDA, FFM. and PRANDINI, FL., 1981. Mapa geomorfológico do estado de São Paulo (Vol. I). São Paulo: IPT. p. 38-41. Monografias, vol. 1.

POOF, NLR. and ALLAN, JD., 1995. Functional organization of stream fish assemblages in relation to hydrological variability. Ecology, vol. 76, no. 2, p. 606-627. http://dx.doi.org/10.2307/1941217.

RONDINELI, GR., 2010. Ictiofauna de duas microbacias - ribeirão dos Buenos e rio Guaratinguetá - na serra da Mantiqueira oriental. Rio Claro: Universidade Estadual Paulista. 175 p. Tese de Doutorado em Ciências Biológicas (Zoologia).

RONDINELI, GR., CARMASSI, AL. and BRAGA, FMS., 2011. Pisces, Buenos and Guaratinguetá watersheds, eastern serra da Mantiqueira, Brazil. Check List, vol. 7, no. 1, p. 71-74.

SCHLOSSER, IJ., 1982. Fish community structure and function along two habitat gradients in a headwater stream. Ecological Monographs, vol. 52, no. 4, p. 395-414. http://dx.doi.org/10.2307/2937352.

SIEGEL, S., 1975. Estatística não-paramétrica: para as ciências do comportamento. São Paulo: McGraw-Hill do Brasil.

TAYLOR, CM., WINSTON, MR. and MATTHEWS, WJ., 1993. Fish species-environment and abundance relationships in a Great Plains river system. Ecography, vol. 16, no. 1, p. 16-23. http:// dx.doi.org/10.1111/j.1600-0587.1993.tb00054.x.

TAYLOR, CM., WINSTON, MR. and MATTHEWS, WJ., 1996. Temporal variation in tributary and mainstream fish assemblages in a Great Plains stream system. Copeia, vol. 1996, no. 2, p. 280289. http://dx.doi.org/10.2307/1446844.

VANZOLINI, PE., 1993. Métodos estatísticos elementares em sistemática zoológica. São Paulo: Hucitec.

WOOTTON, RJ., 1992. Fish ecology. New York: Chapman \& Hall. 